\title{
Autonomous Adenomas Caused by Somatic Mutations of the Thyroid-Stimulating Hormone Receptor in Children
}

\author{
Francisca Groba,d Johnny Deladoëy ${ }^{a}$ Laurent Legault ${ }^{c}$ Linda Spigelblatt ${ }^{c}$ \\ Anne Fournier $^{\mathrm{b}}$ Gilbert Vassart ${ }^{\mathrm{e}}$ Guy Van Vliet ${ }^{\mathrm{a}}$ \\ ${ }^{a}$ Endocrinology Service and Research Center and ${ }^{b}$ Cardiology Service, Centre Hospitalier Universitaire Sainte-Justine \\ and Department of Pediatrics, University of Montreal, ' 'Department of Pediatrics, Hôpital Maisonneuve-Rosemont \\ and University of Montreal, Montreal, Que., Canada; ${ }^{d}$ Pediatric Endocrinology Unit, Division of Pediatrics, Pontificia

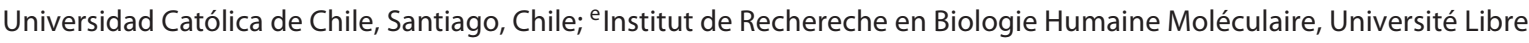 \\ de Bruxelles, Brussels, Belgium
}

\section{Key Words}

Hyperthyroidism · Hot nodule - Somatic mutation .

Thyroid cancer $\cdot$ Mitral valve prolapse

\begin{abstract}
In adults, autonomous adenomas of the thyroid causing hyperthyroidism are relatively common and are most often due to somatic mutations that increase the constitutive activity of the thyroid-stimulating hormone receptor (TSHR). By contrast, autonomous adenomas in hyperthyroid children are exceptional and reports of their clinical and molecular characteristics are few. We reviewed papers describing 16 autonomous adenomas due to a somatic mutation activating the TSHR and diagnosed in patients younger than 18 years, to which we added two of our own unpublished observations in a 4- and 8-year-old with the same TSHR mutation (c.CAG>CAC; p.Asp633His). This revealed that (a) autonomous adenomas occur more often in the right lobe (11 of 14 with available information) and the associated hyperthyroidism tends to be more severe, possibly reflecting the richer vascular supply of the right thyroid lobe, and (b) mutations found in benign adenomas in children have been associated with cancer in adults, suggesting that malignancy requires a second 'hit' at a later age.

(c) 2014 S. Karger AG, Basel
\end{abstract}

\section{Introduction}

The first description of somatic mutations increasing the constitutive activity of the thyroid-stimulating hormone receptor (TSHR) as a potential cause of autonomous adenomas of the thyroid in hyperthyroid adults was published 20 years ago [1]. Since then, a number of reviews have established that this is the principal cause of autonomous adenomas in adults [2,3]. Similar reviews of autonomous adenomas caused by TSHR mutations focusing on pediatric patients have not been published, probably because thyroid nodules, including autonomous adenomas, are encountered much less frequently in patients younger than 18 years than in adulthood $[4,5]$. This review addresses the clinical and molecular features of autonomous adenomas occurring in children bearing a mutation in TSHR.

Autonomous adenomas are well defined, encapsulated and nearly always benign tumors characterized by autonomous secretion of thyroid hormones [6]. In addition to the somatic activating mutations of TSHR mentioned above, autonomous adenomas can also, albeit more rarely [7], be due to mutations activating GNAS, the gene encoding the Gsa protein. Both TSHR and Gsa activation result in increased cAMP production in thyroid follicular cells. The affected cells display unregulated functional ac-

\section{KARGER}

E-Mail karger@karger.com

www.karger.com/hrp
(C) 2014 S. Karger AG, Basel

1663-2818/14/0812-0073\$39.50/0
Guy Van Vliet

CHU Sainte-Justine, Room 1719

3175, chemin de la Côte-Ste-Catherine

Montréal, QC H3T 1C5 (Canada)

E-Mail guy.van.vliet@umontreal.ca 
Fig. 1. a TSHR is located on chromosome 14 and is composed of 10 exons. It encodes a member of the glycoprotein hormone receptor family of G-protein-coupled receptors whose activity is mediated by adenylyl cyclase. b TSHR activation stimulates the growth and differentiation of thyrocytes and the secretion of thyroid hormones.

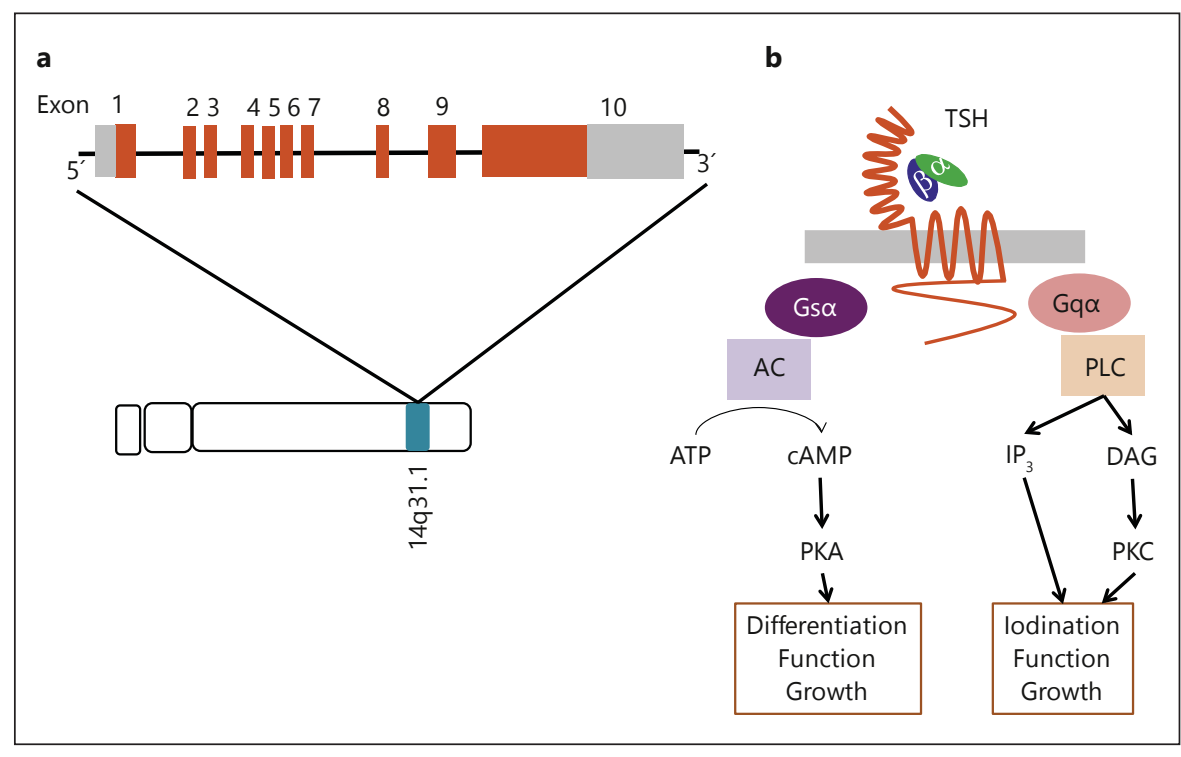

tivity and clonally expand to form a lesion that progressively takes over the function of the normal tissue [3].

Activating TSHR mutations also underlie two other syndromes: familial non-autoimmune hyperthyroidism $[8,9]$ and sporadic congenital non-autoimmune hyperthyroidism [10]. These result from germline mutations leading to the whole thyroid gland being affected and have been extensively reviewed elsewhere [11].

\section{Methods}

We searched PubMed and the TSHR mutation database (http:// endokrinologie.uniklinikum-leipzig.de/tsh/) with the following criteria: toxic or autonomous adenoma and children. This yielded 8 publications $[2,12-18]$ describing 16 autonomous adenomas in which a somatic TSHR mutation had been documented in 14 patients younger than 18 years ( 1 patient had 3 autonomous adenomas). To these, we added 2 of our own unpublished patients, who are described in detail below. Data collected included age at diagnosis, sex, affected thyroid lobe, nodule size and thyroid function when available.

In our 2 patients, informed consent for molecular genetic analysis was obtained from the parents. DNA was extracted from the thyroid nodule, from adjacent thyroid tissue and from leukocytes, and amplified by PCR followed by direct sequencing of exon 9 and part of exon 10 (from residue 430) of TSHR.

\section{The Thyroid-Stimulating Hormone Receptor (fig. 1)}

The TSHR gene is located on the long arm of chromosome 14 and encodes a 764-amino-acid protein with a molecular weight of 86,830 daltons [19]. TSHR is a mem- ber of the glycoprotein hormone receptor family of Gprotein-coupled receptors (GPCRs), and is characterized by a large $\mathrm{N}$-terminal ectodomain, encoded by the first 9 exons of the gene; seven transmembrane segments and an intracytoplasmic domain with a carboxyl-terminal segment encoded by exon 10. Its long amino-terminal segment is responsible for high affinity binding of TSH. Figure 1 shows how the TSHR initiates intracellular signaling by activating $G$ proteins that regulate the activity of effector molecules: the Gs protein, leading to the stimulation of the cyclic cAMP cascade, and, at higher TSH concentrations, the Gq protein, activating the phospholipase C (PLC) cascade. cAMP binds to protein kinase A (PKA), permitting enhanced activity of its catalytic subunit that phosphorylates different effectors. Activation of PLC leads to the generation of inositol 1,4,5-triphosphate $\left(\mathrm{IP}_{3}\right)$ and diacylglycerol (DAG), whose functions are related to promoting the release of $\mathrm{Ca}^{2+}$ into the cytoplasm and activation of the protein kinase C (PKC) pathway. Somatic mutations of the TSHR or Gsa proteins constitutively activate the cAMP pathway and induce the clonal expansion and hyperfunction of the thyroid follicular cells. Cells harboring the mutation also have an increased expression of the sodium iodide symporter, which results in a high uptake or 'hot nodule' image on scintigraphy. As synthesis and secretion of thyroid hormone increases by the increasing number of adenoma cells, the negative feedback at the hypothalamic-pituitary level results in suppressed TSH secretion and decreased or absent uptake in the normal thyroid tissue. 
Table 1. Somatic activating mutations of the TSHR in pediatric autonomous adenomas

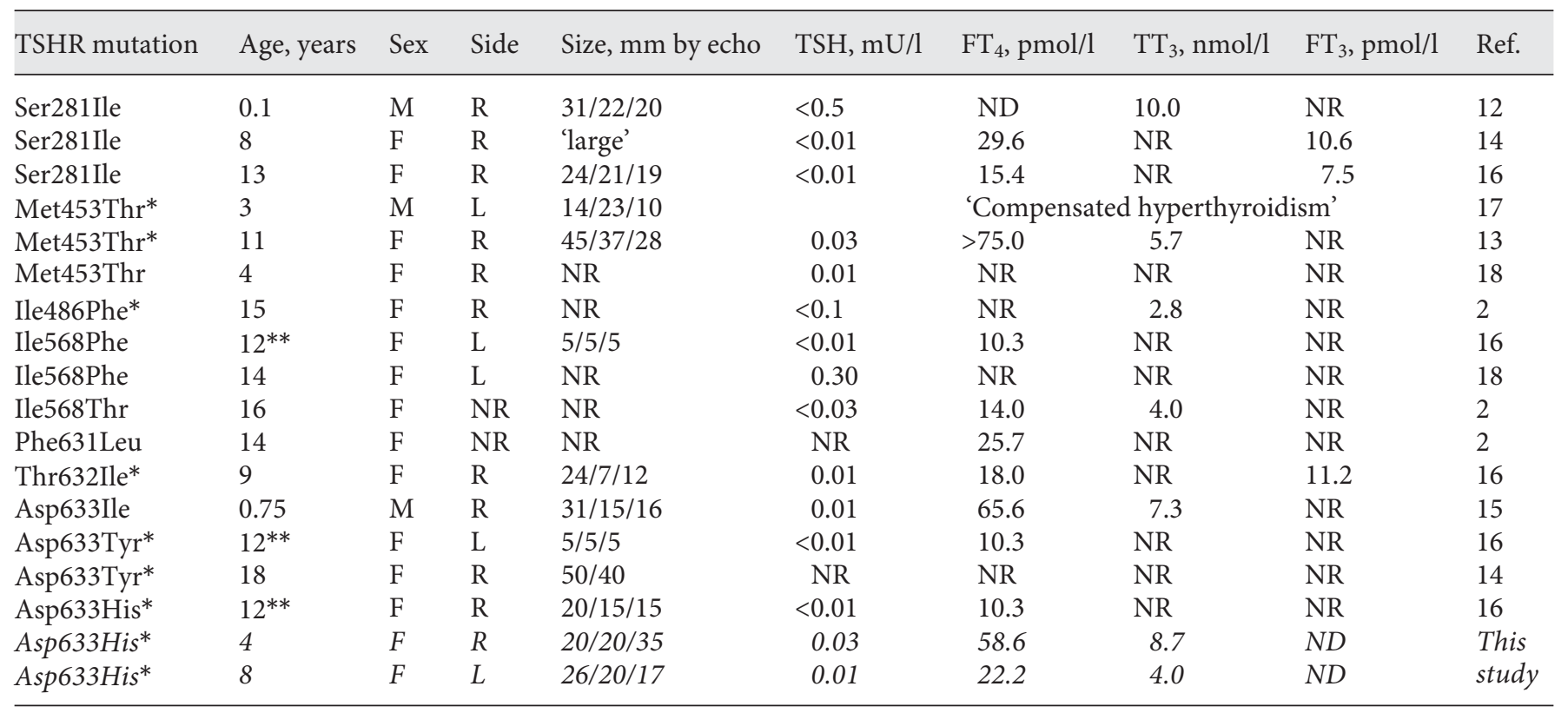

$\mathrm{M}=$ Male; $\mathrm{F}=$ female $\mathrm{R}=$ right $\mathrm{L}=$ left $\mathrm{NR}=$ not reported; $\mathrm{ND}=$ not done. ${ }^{*}$ Also found in carcinoma in adults: Met453Thr, papillary; Ile486Phe and Thr632Ile, follicular (http://endokrinologie.uniklinikum-leipzig.de/tsh/); Arg633His: insular [38]. ** This patient had 3 nodules, each bearing a different mutation.

\section{Somatic Mutations Activating TSHR in Autonomous Adenomas}

Autonomous adenomas occur as a consequence of an increase in the constitutive (i.e. in the absence of ligand) activity of the TSHR. Most of the mutations are located in the sixth transmembrane domain of the receptor, but they can also be found elsewhere in the serpentine and in a specific residue (Ser281) of the extracellular domain of the receptor [11], switching it from an inverse agonist to an agonist of the serpentine domain [20]. Some of the mutations found in autonomous adenomas are also present in the other two forms of non-immune hyperthyroidism, but are more frequently associated with its sporadic form. This suggests that familial transmission of TSHR activating mutations is more likely to occur for mutations that have a less pronounced effect and therefore do not interfere with reproductive fitness [21].

The somatic TSHR mutations in autonomous adenomas diagnosed in patients less than 18 years are listed on table 1. Whereas in adults the commonest TSH mutations found in autonomous adenomas are at residue 632 (Sanger Institute Catalogue of Somatic Mutations in Cancer: http://www.sanger.ac.uk/cosmic), mutations at the neighboring residue 633 account for $6 / 18$ autonomous adenomas in children. In addition, several of the mutations (noted by an asterisk in table 1) encountered in children with benign autonomous adenomas have also been reported in adults with malignant autonomous nodules.

\section{Pathogenesis of Autonomous Adenomas}

Once a somatic mutation has occurred, the thyroid cell has to divide successfully to form a clinically apparent autonomous adenoma. It has been estimated that at least 30 divisions would be required to reach a critical size [22]. This number is considerably higher than the number of divisions that are estimated to occur in an adult thyrocyte (5-7) [23]. In autonomous adenomas, telomere shortening [24] and the loss of negative feedback control [25] are consistent with rapid proliferation. However, the mitotic index observed in thyrocytes obtained from autonomous adenomas at the time of surgery is not consistent with rapid cell division [22]. The explanation is probably that, by the time of diagnosis, the lesions are no longer growing: supporting this explanation is the observation that, once an autonomous adenoma is diagnosed a further increase in size occurs in only a small percentage of cases [6]. 
Table 2. Patients' characteristics at diagnosis

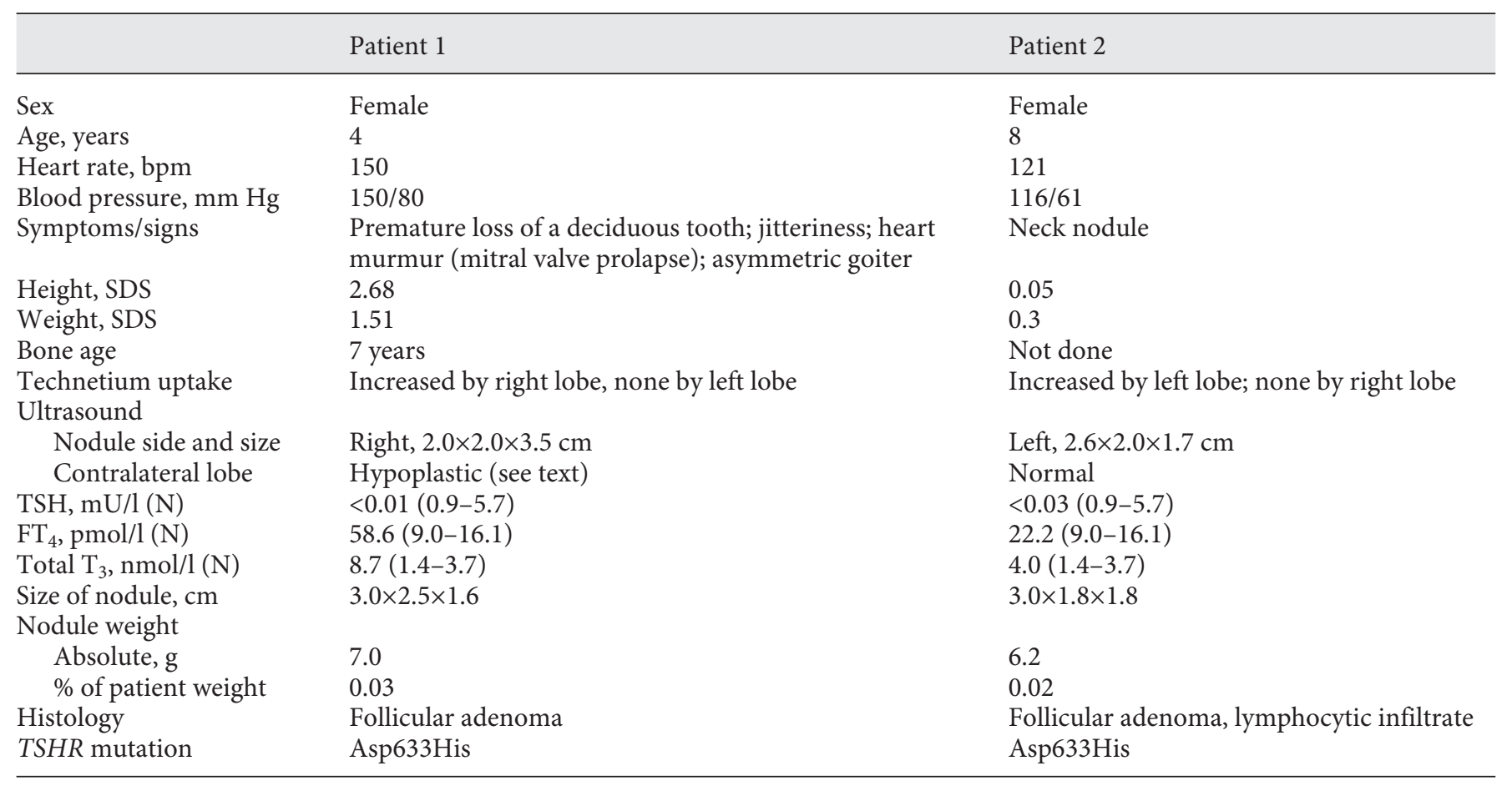

SDS = Standard deviation score $\mathrm{N}=$ normal values .

\section{Clinical Presentation of 16 Patients}

Sixteen autonomous adenomas harboring an activating TSHR mutation in 14 patients under the age of 18 years have been reported in the literature (table 1). To these, we add 2 previously unreported girls from our own institution. These 2 girls, aged 4 and 8 years at diagnosis, presented with a benign autonomous adenoma that was due to the same somatic mutation in the TSHR gene but with very different clinical features and postoperative evolutions. These are described below.

Patient 1 was noted to have marked tachycardia, a heart murmur, hypertension and an asymmetric goiter at a routine visit, prompted by the premature loss of a deciduous tooth at the age of 4 years. The parents also reported increasing jitteriness over the last 6 months. Linear growth had accelerated with relative weight loss. Clinical, biochemical, imaging, histological and molecular data are depicted in table 2. A diagnosis of non-autoimmune hyperthyroidism due to an autonomous adenoma with associated mitral valve prolapse was made. The patient was put on $\beta$-blockers and a right hemithyroidectomy was performed 2 weeks later. A well-encapsulated nodule was found to occupy most of the right lobe; the left lobe was hardly visible. The pathological diagnosis was benign follicular adenoma. Two weeks after surgery, the patient became profoundly hypothyroid $\left[\mathrm{FT}_{4} 3.2 \mathrm{pmol} / \mathrm{l}\right.$ (N 9.0-16.1)], although TSH was still suppressed at 0.03 $\mathrm{mU} / \mathrm{l}(\mathrm{N} 0.9-5.7)$, only rising to $29.94 \mathrm{mU} / \mathrm{l}$ one month later. The patient was then started on levothyroxine treatment $(50 \mu \mathrm{g}$ daily). Consistent with partial catch-up growth of the left thyroid lobe from $0.45 \mathrm{ml}(-2.8 \mathrm{SD})$ at diagnosis to $0.88 \mathrm{ml}(-2.3 \mathrm{SD}) 2$ years later [26], serum TSH only rose to $6.64 \mathrm{mU} / \mathrm{l}$ after a 1 -month withdrawal of levothyroxine 3 years after surgery. 'Catch-down' growth after surgery resulted in an adult height within the target range (fig. 2). Nine years after thyroidectomy, the mitral valve prolapse had disappeared and thyroid function had become normal off levothyroxine (serum TSH: $3.66 \mathrm{mU} / \mathrm{l})$.

Patient 2 presented at 8 years of age with progressive enlargement of the left side of the neck. On physical examination, there was mild tachycardia and the thyroid was enlarged with a palpable, non-tender, mobile nodule of the left lobe. Clinical, biochemical, imaging, histological and molecular data are depicted in table 2. At surgery, a well-encapsulated nodule was found. The pathological diagnosis was benign follicular adenoma. The tissue sur- 


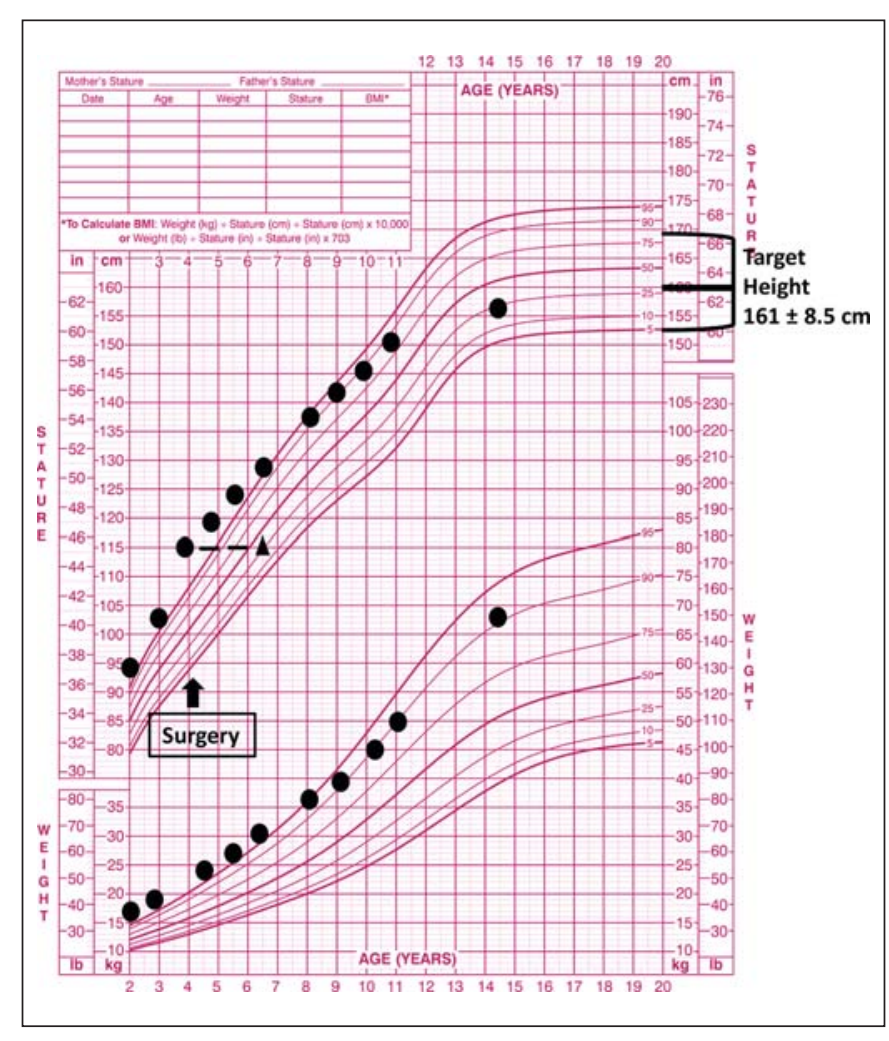

Fig. 2. Growth chart of patient 1 . An abrupt increase in height velocity was noted between 3 and 4 years of age and a significant advancement of bone age was documented at the time of surgery (triangle). After treatment, 'catch-down' growth was observed and adult height was within the target height range.

rounding the nodule showed a marked lymphocytic infiltrate. One month after surgery, serum TSH rose to 6.55 $\mathrm{mU} / \mathrm{l}$ but normalized spontaneously 3 months later and remained normal over the subsequent 7 years.

In both patients, the same mutation in exon 10, codon 633, of TSHR (c.GAC>CAC), which results in the substitution of aspartic acid by histidine (p.Asp633His), was found in the heterozygous state in the thyroid nodule, but neither in the adjacent normal thyroid tissue nor in the lymphocytes, indicating a somatic mutation. This mutation is located in the sixth transmembrane segment of the TSHR. Table 2 summarizes the characteristics of our patients at diagnosis.

Children with autonomous adenomas of the thyroid are usually brought to medical attention because of a cervical mass or because of signs of hyperthyroidism (often restricted to tachycardia). In young children with Graves' disease, there may be acceleration of linear growth and of bone maturation [27], but our patient 1 shows that this can be observed in non-autoimmune hyperthyroidism as well (table 2); furthermore, long-term follow-up shows that adult height was within the target range (fig. 2). Such linear growth acceleration is not as pronounced in older children with hyperthyroidism due to either Graves' disease $[28,29]$ or to an autonomous adenoma (our patient 2). A distinctive feature of autonomous adenomas is the absence of ophthalmopathy and the absence of antibodies to the TSHR, which are the hallmark of Graves' disease. A thyroid nodule in a child with clinical and biochemical hyperthyroidism has to be further assessed with a thyroid scintigraphy, to evaluate its autonomy [5]. The presence of a 'hot nodule' confirms the diagnosis and surgical excision is recommended to cure the hyperthyroidism and also because even autonomous nodules can be malignant [13].

Table 1 lists all reported pediatric cases of somatic gain of function mutations of the TSHR, including those described in the present report. Age at diagnosis and severity of hyperthyroidism was very variable, with some patients having normal $\mathrm{FT}_{4}$, but elevated total or $\mathrm{FT}_{3}$ concentrations. Table 2 shows that the degree of hyperthyroidism of our 4-year-old patient was much more severe, and possibly more protracted, than that of the 8 -year-old in spite of both patients having the same somatic mutation in TSHR and both autonomous adenomas having the same weight relative to body size. This may result from the fact that the autonomous adenoma in patient 1 was in the right thyroid lobe, which is more richly vascularized than the left [30]. Asymmetry of the arterial supply may also explain why autonomous adenomas occur much more often in the right lobe in both children [4] and adults [31] and in the patients reviewed here (11 out of 14 with available information, table 1). It is also possible that other genes or environmental factors such as iodine intake modify the expression of the TSHR mutation; indeed, phenotypic variability between family members with the same germline mutation activating TSHR has also been described [32]. The relationship between mitral valve prolapse and hyperthyroidism due to either Graves' disease [33, 34] or TSHR-activating mutations [35] is controversial but the progressive reversibility of the latter after correction of the former in our patient 1 strongly suggests a causal relationship. Lastly, the severe and slowly reversible atrophy of the contralateral lobe in patient 1 extends to the thyroid the concept of disuse atrophy, which is well established in the contralateral adrenal of patients with a cortisol-producing adenoma [36].

As shown in table 1, several mutations found in 9 pediatric autonomous adenomas, which are benign lesions, have also been reported in malignant hot nodules in adults 
(Sanger Institute Catalogue of Somatic Mutations in Cancer: http://www.sanger.ac.uk/cosmic). This might suggest that these mutations are associated with relatively rapid growth of adenomas, thus facilitating the later occurrence of a second oncogenic 'hit' [13]. This interpretation is supported by the restricted spectrum of mutations in children, with mutation of Asp633 appearing to be particularly frequent and leading to relative large adenomas (table 1). Of note, in the LH receptor, only the Asp578His somatic mutation, which is homologous to Asp633 in TSHR, causes Leydig cell adenomas in children [37]. It is also worth stressing that the Asp633His mutation found in our patients has been found in a 60-year-old woman with the most aggressive type of differentiated thyroid cancer, insular carcinoma [38]. Taken together, these data suggest that mutations at residue 633 in TSHR cause more pronounced proliferation than the others, leading to their being recognized in the pediatric age group and being a higher risk factor for malignancy in adulthood.

\section{Conclusions}

We review 18 autonomous adenomas (including 2 previously unpublished cases) of the thyroid caused by a somatic mutation activating the TSHR and diagnosed in patients aged less than 18 years. In the 2 previously unpublished cases, who had the same TSHR mutation, hyperthyroidism was much more severe in the 4-year-old than in the 8-year-old; this did not appear to be related to the relative weight of the autonomous adenoma and may be related to the fact that the autonomous adenoma of the 4 -year-old was in the right lobe, which receives a richer vascular supply. The richer vascular supply of the right thyroid lobe may also account for the more frequent occurrence of autonomous adenomas, both with (table 1) and without a documented TSHR mutation, on that side. On the other hand, the overall review also suggests that TSHR mutations causing benign autonomous adenomas in children might be associated with cancer in adults, implying that malignancy requires a second hit at a later age.

\section{Acknowledgements}

We thank Dr. Dickens St.-Vil for expert surgery on both patients, Dr. Jasmine Parma for supervising the molecular analyses and Dr. Massimo Tonacchera for providing additional information on the patients described in reference 18 .

Research in pediatric thyroid diseases at the Centre Hospitalier Universitaire Sainte-Justine is supported by the Girafonds/CHU Sainte-Justine Foundation (private donations to G.V.V. and J.D.). F.G. is a clinical fellow supported by a grant from the Chilean Society of Endocrinology (SOCHED) and the Latin American Society for Pediatric Endocrinology (SLEP).

\section{Disclosure Statement}

The authors have no conflicts of interest to disclose.

\section{References}

1 Parma J, Duprez L, Van Sande J, Cochaux P, Gervy C, Mockel J, Dumont J, Vassart G: Somatic mutations in the thyrotropin receptor gene cause hyperfunctioning thyroid adenomas. Nature 1993;365:649-651.

-2 Parma J, Duprez L, Van Sande J, Hermans J, Rocmans P, Van Vliet G, Costagliola S, Rodien P, Dumont JE, Vassart G: Diversity and prevalence of somatic mutations in the thyrotropin receptor and Gsa genes as a cause of toxic thyroid adenomas. J Clin Endocrinol Metab 1997;82:2695-2701.

3 Krohn K, Fuhrer D, Holzapfel HP, Paschke R: Clonal origin of toxic thyroid nodules with constitutively activating thyrotropin receptor mutations. J Clin Endocrinol Metab 1998;83: 130-134.

-4 Niedziela M, Breborowicz D, Trejster E, Korman E: Hot nodules in children and adolescents in western Poland from 1996 to 2000: clinical analysis of 31 patients. J Pediatr Endocrinol Metab 2002;15:823-830.
5 Gupta A, Ly S, Castroneves LA, Frates MC, Benson CB, Feldman HA, Wassner AJ, Smith JR, Marqusee E, Alexander EK, Barletta J, Doubilet PM, Peters HE, Webb S, Modi BP, Paltiel HJ, Kozakewich H, Cibas ES, Moore FD Jr, Shamberger RC, Larsen PR, Huang SA: A standardized assessment of thyroid nodules in children confirms higher cancer prevalence than in adults. J Clin Endocrinol Metab 2013; 98:3238-3245.

6 Hamburger JI: The autonomously functioning thyroid nodule: Goetsch's disease. Endocr Rev 1987;8:439-447.

7 Corvilain B, Van Sande J, Dumont JE, Vassart G: Somatic and germline mutations of the TSH receptor and thyroid diseases. Clin Endocrinol (Oxf) 2001;55:143-158.

8 Thomas JS, Leclere J, Hartemann P, Duheille J, Orgiazzi J, Petersen M, Janot C, Guedenet JC: Familial hyperthyroidism without evidence of autoimmunity. Acta Endocrinol (Copenh) 1982;100:512-518.
-9 Duprez L, Parma J, Van Sande J, Allgeier A, Leclere J, Schvartz C, Delisle MJ, Decoulx M, Orgiazzi J, Dumont J: Germline mutations in the thyrotropin receptor gene cause non-autoimmune autosomal dominant hyperthyroidism. Nat Genet 1994;7:396-401.

10 Kopp P, Van Sande J, Parma J, Duprez L, Gerber H, Joss E, Jameson JL, Dumont JE, Vassart G: Brief report: congenital hyperthyroidism caused by a mutation in the thyrotropin-receptor gene. N Engl J Med 1995;332:150-154.

-11 Hebrant A, van Staveren WC, Maenhaut C, Dumont JE, Leclere J: Genetic hyperthyroidism: hyperthyroidism due to activating TSHR mutations. Eur J Endocrinol 2011;164:1-9.

-12 Kopp P, Muirhead S, Jourdain N, Gu WX, Jameson JL, Rodd C: Congenital hyperthyroidism caused by a solitary toxic adenoma harboring a novel somatic mutation (serine281 $\rightarrow$ isoleucine) in the extracellular domain of the thyrotropin receptor. J Clin Invest 1997;100:1634-1639. 
$>13$ Mircescu H, Parma J, Huot C, Deal C, Oligny LL, Vassart G, Van Vliet G: Hyperfunctioning malignant thyroid nodule in an 11-year-old girl: pathologic and molecular studies. J Pediatr 2000;137:585-587.

14 Nanba K, Usui T, Minamiguchi S, Mori Y, Watanabe Y, Honda K, Asato R, Nakao K, Kawashima ST, Yuno A, Tamanaha T, Tagami T, Naruse M, Akiyama Y, Shimatsu A: Two rare TSH receptor amino acid substitutions in toxic thyroid adenomas. Endocr J 2012;59:1319.

15 Kohn B, Grasberger H, Lam LL, Ferrara AM, Refetoff S: A somatic gain-of-function mutation in the thyrotropin receptor gene producing a toxic adenoma in an infant. Thyroid 2009; 19:187-191.

-16 Schwab KO, Pfarr N, van der Werf-Grohmann N, Pohl M, Radecke J, Musholt T, Pohlenz J: Autonomous thyroid adenoma: only an adulthood disease? J Pediatr 2009;154:931-933.

$\checkmark 17$ Kraemer S, Rothe K, Pfaeffle R, Fuehrer-Sakel $\mathrm{D}$, Till H, Muensterer OJ: Activating TSH-receptor mutation (Met453Thr) as a cause of adenomatous non-autoimmune hyperthyroidism in a 3-year-old boy. J Pediatr Endocrinol Metab 2009;22:269-274.

-18 Agretti P, Segni M, De MG, Ferrarini E, Di CC, Corrias A, Weber G, Larizza D, Calcaterra V, Pelizzo M, Cesaretti G, Vitti P, Tonacchera M: Prevalence of activating thyrotropin receptor and Gsa gene mutations in paediatric thyroid toxic adenomas: a multicentric Italian study. Clin Endocrinol (Oxf) 2013;79: 747-749.

19 Parmentier M, Libert F, Maenhaut C, Lefort A, Gerard C, Perret J, Van Sande J, Dumont JE, Vassart G: Molecular cloning of the thyrotropin receptor. Science 1989;246:1620-1622.

20 Vlaeminck-Guillem V, Ho SC, Rodien P, Vassart G, Costagliola S: Activation of the cAMP pathway by the TSH receptor involves switching of the ectodomain from a tethered inverse agonist to an agonist. Mol Endocrinol 2002; 16:736-746.
21 Duprez L, Parma J, Van Sande J, Rodien P, Sabine C, Abramowicz M, Dumont JE, Vassart G: Pathology of the TSH receptor. J Pediatr Endocrinol Metab 1999;12(suppl 1):295302.

22 Deleu S, Allory Y, Radulescu A, Pirson I, Carrasco N, Corvilain B, Salmon I, Franc B, Dumont JE, Van Sande J, Maenhaut C: Characterization of autonomous thyroid adenoma: metabolism, gene expression, and pathology. Thyroid 2000;10:131-140.

23 Coclet J, Foureau F, Ketelbant P, Galand P, Dumont JE: Cell population kinetics in dog and human adult thyroid. Clin Endocrinol (Oxf) 1989;31:655-665.

24 De Deken X, Vilain C, Van Sande J, Dumont JE, Miot F: Decrease of telomere length in thyroid adenomas without telomerase activity. J Clin Endocrinol Metab 1998;83:4368-4372.

25 Van Staveren WC, Solis DW, Delys L, Venet D, Cappello M, Andry G, Dumont JE, Libert F, Detours V, Maenhaut C: Gene expression in human thyrocytes and autonomous adenomas reveals suppression of negative feedbacks in tumorigenesis. Proc Natl Acad Sci USA 2006;103:413-418.

26 Chanoine JP, Toppet V, Lagasse R, Spehl M, Delange F: Determination of thyroid volume by ultrasound from the neonatal period to late adolescence. Eur J Pediatr 1991;150:395-399.

27 Segni M, Leonardi E, Mazzoncini B, Pucarelli I, Pasquino AM: Special features of Graves' disease in early childhood. Thyroid 1999;9: 871-877.

28 Buckler JM, Willgerodt H, Keller E: Growth in thyrotoxicosis. Arch Dis Child 1986;61: 464-471.

29 Van Veenendaal NR, Rivkees SA: Treatment of pediatric Graves' disease is associated with excessive weight gain. J Clin Endocrinol Metab 2011;96:3257-3263.
0 Toni R, Della CC, Mosca S, Malaguti A, Castorina S, Roti E: Anthropological variations in the anatomy of the human thyroid arteries. Thyroid 2003;13:183-192.

-31 Burch HB, Shakir F, Fitzsimmons TR, Jaques DP, Shriver CD: Diagnosis and management of the autonomously functioning thyroid nodule: the Walter Reed Army Medical Center experience, 1975-1996. Thyroid 1998;8: 871-880.

-32 Akcurin S, Turkkahraman D, Tysoe C, Ellard S, De Leener A, Vassart G, Costagliola S: A family with a novel TSH receptor activating germline mutation (p.Ala485Val). Eur J Pediatr 2008;167:1231-1237.

33 Carceller AM, Fouron JC, Letarte J, Ducharme G, van Doesburg NH, Mauran P, Davignon A: Absence of mitral valve prolapse in juvenile hyperthyroidism. Am J Cardiol 1984; 54:455-456.

34 Liu YP, Tsai WY, Wang JK, Wu MH: Reversible mitral valve prolapse and mitral regurgitation in children with Graves' disease. J Pediatr Endocrinol Metab 2004;17:1211-1213.

35 Khoo DH, Parma J, Rajasoorya C, Ho SC, Vassart G: A germline mutation of the thyrotropin receptor gene associated with thyrotoxicosis and mitral valve prolapse in a Chinese family. J Clin Endocrinol Metab 1999;84:1459-1462.

36 Raine JE, Donaldson MD, Gregory JW, Van Vliet G: Practical Endocrinology and Diabetes in Children, ed 3. Oxford, Wiley-Blackwell, 2011.

37 Liu G, Duranteau L, Carel JC, Monroe J, Doyle DA, Shenker A: Leydig cell tumors caused by an activating mutation of the gene encoding the luteinizing hormone receptor. N Engl J Med 1999;341:1731-1736.

-38 Russo D, Tumino S, Arturi F, Vigneri P, Grasso G, Pontecorvi A, Filetti S, Belfiore A: Detection of an activating mutation of the thyrotropin receptor in a case of an autonomously hyperfunctioning thyroid insular carcinoma. J Clin Endocrinol Metab 1997;82:735-738. 